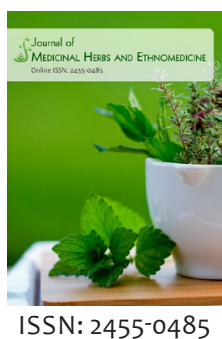

Received: June 03, 2019 Accepted: January 25, 2020 Published: February 08, 2020

*Corresponding Author: E.O. Agbaje

Email: estheragbaje01@gmail. com, eagbaje@unilag.edu.ng

\section{Antimicrobial and antipyretic activities of aqueous leaf extract of Spondias mombin Linn. (Anarcadiaceae)}

\author{
E.O. Agbaje ${ }^{1 *}$, A.I. Ismail', O.J. Oguntokun² \\ 'Department of Pharmacology, Therapeutics \& Toxicology, Faculty of Basic Medical Sciences, College of Medicine, \\ University of Lagos, Pmb 12003, Lagos, Nigeria, 2Department of Pharmacology and Toxicology, Faculty of \\ Pharmaceutical Sciences, University of Jos, Jos-Plateau StaSte, Nigeria
}

\begin{abstract}
Spondias mombin (Linn.) (Anacardiaceae) is an herbaceous plant widely used in Traditional African medicine (TAM) for the treatment of diverse ailments including infections and febrile conditions. This study was conducted to investigate the antimicrobial and antipyretic properties of the aqueous leaf extract of $S$. mombin. The sensitivity test (using zones of inhibition), minimum inhibitory concentration and minimum bactericidal concentration tests were used to investigate its antimicrobial properties, while the 2,4-dinitrophenol (DNP)- and yeast-induced hyperthermia tests were used to investigate antipyretic activity in rodents. S. mombin $\left(50,100\right.$ and $200 \mathrm{mg} \mathrm{kg}^{-1}$, p.o) produced significant $(p<0.05)$ antimicrobial activity in the sensitivity test. The effects of 50,100 and $200 \mathrm{mg} / \mathrm{ml} \mathrm{S}$. mombin were generally comparable to those of ciprofloxacin. Also, S. mombin produced significant $(p<0.05)$ reduction of elevated temperature in the 2,4-DNP and yeast-induced hyperthermia models with peak effects of anti-pyrexia produced at $200 \mathrm{mg} \mathrm{kg}^{-1}$ for 2,4-DNP induced hyperthermia and $100 \mathrm{mg} \mathrm{kg}^{-1}$ for the yeast-induced. The effect at these doses was comparable to that of paracetamol, being the positive control in the two models. The results obtained in this study demonstrated that the aqueous leaf extract of Spondias mombin possesses antibacterial and antipyretic properties.
\end{abstract}

KEYWORDS: Antimicrobial, antipyretic, Spondias mombin, extract

\section{INTRODUCTION}

Pyrexia or fever is a natural reaction during a number of illnesses. Fever is usually accompanied by different general symptoms, such as sweating, chills, sensation of cold and other subjective sensations. Absence of these symptoms during high temperature may be a sign of a serious illness. Causes of fever include infections due to microbes such as viruses and bacteria, as well as immune reactions (including the defects in collagen, immunological abnormalities and acquired immunodeficiency). Other causes of fever are destruction of tissues, such as trauma, local necrosis (infarction), and inflammatory reactions in tissues and vessels (phlebitis, arthritis), pulmonary infarction, and rhabdomyolysis [1].

Microbial infection is the exposure of the body tissues to disease-causing agents, their multiplication, and how the host tissues react to the infectious agents and the toxins they produce. Hosts can combat infection with their innate immune system, howbeit, specific medications used to treat microbial infections include antibacterial, antifungals, antivirals and other antimicrobial drugs. Infectious diseases resulted in 9.2 million deaths in 2013 (about $17 \%$ of all deaths) [2]. Hence, the impact of microbial infection is very alarming and a lot of antimicrobial agents are in use, but many have been confronted with microbial resistance [3], thus the WHO is encouraging the use of traditional medicine in combating many health issues. WHO (2008) defined traditional medicine as the sum total of knowledge, skills and practices based on the theories, beliefs and experience indigenous to different cultures that are used to maintain health as well as prevent, improve and treat physical/ mental illness [4].

Modern medicine has made incredible advances in the detection of many diseases, particularly those caused by infectious agents - virus and bacteria. Traditional medicine is made of unscientific knowledge system that developed over generations within various societies before the era of modern medicine. WHO also notes that inappropriate use of traditional medicine or practices can have negative effect and that further research is needed to ascertain efficacy and safety.

Countries in Africa, Asia and Latin America use traditional medicine to help meet some of their primary health care needs. In

Copyright: (-) The authors. This article is open access and licensed under the terms of the Creative Commons Attribution License (http://creativecommons.org/licenses/by/4.0/) which permits unrestricted, use, distribution and reproduction in any medium, or format for any purpose, even commercially provided the work is properly cited. Attribution - You must give appropriate credit, provide a link to the license, and indicate if changes were made. 
Africa, up to $80 \%$ of the population use traditional medicine for primary health care. Various plant parts are used in medicine, and research has revealed that the phytoconstituents not only constitute important sources of raw material for industrial processing or preparation of various pure chemical compounds, but also have great potentials in combating diseases of microbial origin [5].

One of the several plants that have recorded multiple folkloric uses in this environment is Spondias mombin (SPM). It occurs in a great variety of humid tropical climates, often in secondary vegetation derived from evergreen lowland forest or semideciduous forest. It has been introduced to most tropical locations and performs well under varied conditions. The tree is tolerant of most soil types and rainfall patterns. Native range include Argentina, Bolivia, Chile, Colombia, Ecuador, French Guiana, Guatemala, Guyana, Honduras, Mexico, Nicaragua, Panama, Paraguay, Peru, Puerto Rico, Surinam, Uruguay, and Venezuela, while the Exotic range include Central African Republic, Congo, Democratic Republic of Congo, Gabon, Gambia, India.

The medicinal uses of the plant include the following: root is taken in form of decoction as purgative, bark is used as an emetic, a remedy for diarrhoea, dysentery, haemorrhoids and a treatment for gonorrhoea. In Mexico, it is used to expel calcification from the bladder, powder for healing wounds. Gum is used as an expectorant and to expel worms. Decoction of the young leaves is a remedy for diarrhoea and dysentery; juice of crushed leaves and powder of dried leaves on wounds and inflammations and also as abortifacients. The fruit juice drink is used as diuretic and febrifuge. Tea from the flower relieves stomach ache, biliousness, urethritis, cystitis and eye and throat inflammation [6].

The present study has been designed to evaluate SPM antimicrobial and antipyretic properties.

\section{MATERIALS AND METHODS}

\section{Materials/Drugs and Chemicalls}

Paracetamol and Clotrimazole) (Emzor Pharmaceuticals), Brewer's Yeast (Kunimed Pharmachem Ltd., Lagos, Nigeria), 2,4- Dinitrophenol (May and baker Nigeria Plc.), Castor oil, Saline, Mueller Hinton agar (Oxoid, England), Saboraud Dextrose Agar (Oxoid, England), Ciprofloxacin standard (Berlin Pharma and Healthcare Limited, Lagos-Nigeria), Tween solution, McFarland Standard.

\section{Collection of Plant}

The fresh leaves of Spondias mombin L. were collected from a garden in Ogun state, Nigeria in the month of July 2017.

\section{Preparation of Leaf Extract}

Leaves were washed under a running tap to remove sand and any other debris, they were thereafter separated from stems and dried at $40^{\circ} \mathrm{C}$ till a constant weight was obtained at three consecutive weighing days apart. The dried leaves $(517.7 \mathrm{~g})$ were shredded with hands and soaked in $3.50 \mathrm{~L}$ of boiled distilled water for 3 days, after which it was filtered with a clean white handkerchief. The filtrate was oven dried at a temperature of $40^{\circ} \mathrm{C}$ to obtain granules referred to as the extract from which different concentrations were made with the appropriate solvents.

$$
\begin{gathered}
\text { Percentage yield was } \\
\text { calculated as }
\end{gathered} \frac{\text { weight of extract }}{\text { Weight of shredded dried leaves }}
$$

\section{Phytochemical Analysis of the Leaf Extracts of Spondias Mombin}

The dry extract was suspended in distilled water and $100 \mathrm{mg} / \mathrm{ml}$ used for phytochemical screening, using standard methods [7].

Quantitative screening of phytoconstituents was also conducted using standard procedures: alkaloids [8], tannins [9], saponins [10], and flavonoids [11].

\section{Antioxidant Assay}

\section{DPPH Radical scavenging activity assay}

The free radical scavenging activity of the extract, based on the scavenging of the stable 1, 1-diphenyl-2-picrylhydrazyl (DPPH) free radical was estimated according to the procedure described by $[12,13]$. An aliquot of $0.5 \mathrm{ml}$ of extract in ethanol $(95 \%)$ at different concentrations $(25,50,75,100 \mu \mathrm{g} / \mathrm{ml})$ was mixed with $2.0 \mathrm{ml}$ of reagent solution $(0.004 \mathrm{~g}$ of DPPH in $100 \mathrm{ml}$ methanol). The control contained only DPPH solution in place of the sample, while methanol was used as blank. The mixture was vigorously shaken and left to stand at a room temperature. After 30 minutes, the decrease in absorbance test mixture (due to quenching of DPPH free radicals) was read at $517 \mathrm{~nm}$. The scavenging effect was calculated using the expression:

$$
\text { \% inhibition }=\frac{\left[\mathrm{A}_{0}-\mathrm{A}_{1}\right]}{\mathrm{A}_{0}} \times 100
$$

Where $A_{0}$ is the absorption of the blank sample and $A_{1}$ is the absorption of the extract.

\section{Nitric oxide scavenging activity assay}

The compound sodium nitroprusside is known to decompose in aqueous solution at physiological $\mathrm{pH}(7.2)$ producing $\mathrm{NO} \bullet$. Under aerobic condition, $\mathrm{NO} \bullet$ reacts with oxygen to produce stable products (nitrate and nitrite), which can be determined using Griess reagent. The absorbance of the chromophore that formed during diazotization of the nitrite with sulphanilamide and subsequent coupling with Naphthylethylenediamine dihydrochloride can be immediately read at $550 \mathrm{~nm}$. A $4 \mathrm{ml}$ sample of plant extract or standard solution of different concentrations $(25,50,75,100 \mu \mathrm{g} / \mathrm{ml})$ were taken in different test tubes and $1 \mathrm{ml}$ of Sodium nitroprusside $(5 \mathrm{mM}$ in phosphate 
buffered saline) solution was added into the test tubes. They were incubated for 2 hours at $30^{\circ} \mathrm{C}$ to complete the reaction. A $2 \mathrm{ml}$ sample was withdrawn from the mixture and mixed with $1.2 \mathrm{ml}$ of Griess reagent (1\% Sulphanilamide, $0.1 \%$ naphthylethylene diamine dihydrochloride in $\left.2 \% \mathrm{H}_{3} \mathrm{PO}_{4}\right)$. The absorbance of the chromophore formed during diazotization of nitrite with sulphanilamide and its subsequent coupling with

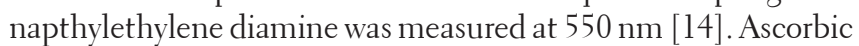
acid was used as standard.

The percentage (\%) inhibition activity was calculated from the following equation:

$$
\frac{\left[\mathrm{A}_{0}-\mathrm{A}_{1}\right]}{\mathrm{A}_{0}} \times 100
$$

\section{Reducing power assay}

Various concentrations of the extracts (20 to $100 \mu \mathrm{g} / \mathrm{ml}$ ) in $1.0 \mathrm{ml}$ of deionized water were mixed with phosphate buffer $(2.5 \mathrm{ml})$ and potassium ferricyanide $(2.5 \mathrm{ml})$, and the mixture was incubated at $50^{\circ} \mathrm{C}$ for $20 \mathrm{~min}$. Aliquots of trichloroacetic acid $(2.5 \mathrm{ml})$ were added to the mixture, which was then cenrifuged at $3000 \mathrm{rpm}$ for $10 \mathrm{~min}$. The upper layer of the solution $(2.5 \mathrm{ml})$ was mixed with distilled water $(2.5 \mathrm{ml})$ and a freshly prepared ferric chloride solution $(0.5 \mathrm{ml}) .{ }^{12}$ The absorbance was measured at $700 \mathrm{~nm}$. A blank was prepared without adding extract. Ascorbic acid at various concentrations ( 1 to $6 \mu \mathrm{g} / \mathrm{ml}$ ) was used as standard. $\%$ Increase in reducing power $=\left(A_{\text {test }} / A_{\text {blank }}\right)-1 \times 100 . A_{\text {test }}$ is absorbance of test solution; $A_{\text {blank }}$ is absorbance of blank.

\section{Experimental Animals}

Albino mice and rats of both sexes obtained from the Laboratory Animal Centre of the College of Medicine, University of Lagos, Idi-Araba, Lagos, Nigeria were used. The animals were maintained under standard laboratory conditions such as temperature $23-25^{\circ} \mathrm{C}, 12$ hour light/dark cycle and provided with standard pellet diet (Neimeth Livestock Feeds Ikeja, Lagos, Nigeria). The animals were allowed to acclimatize for one week under standard environmental conditions.

\section{Acute Toxicity Test}

Albino mice were fasted 24 hours prior to test. The mice were divided into 5 groups and treated intraperitoneally with aqueous extract of SPM at the doses of 10, 100,500, and $1000 \mathrm{mg} / \mathrm{kg}$. The animals were observed for 24 hours for signs of toxicity as well as mortality and the $\mathrm{LD}_{50}$ calculated. The extract was also given orally in doses of 1000, 2000 and $4000 \mathrm{mg} / \mathrm{kg}$ and similarly monitored [15].

The $\mathrm{LD}_{50}$ was calculated using the formula:

$$
\sqrt{ }\left(\mathrm{D}_{0} \times \mathrm{D}_{100}\right)
$$

Where;

$\mathrm{D}_{0}=$ Highest dose that produced no mortality

$\mathrm{D}_{100}=$ Lowest dose that produced $100 \%$ mortality.

\section{Experimental Procedures}

\section{Antipyretic test}

The antipyretic effect of the extract SPM was assessed using the following models:

2,4- Dinitrophenol (DNP)-induced pyrexia test

Brewer's Yeast-induced pyrexia test

\section{2,4-Dinitrophenol-Induced Pyrexia}

The animals were fasted for $12 \mathrm{~h}$ ad libitum. The basal anal temperature of rats fasted were measured using a digital thermometer and recorded as $\left(\mathrm{T}_{0}^{\circ} \mathrm{C}\right) .2,4-\mathrm{DNP}$ (prepared at a concentration of $1 \mathrm{mg} / \mathrm{ml}$ in $0.9 \%$ sodium chloride solution) was administered intraperitoneally as the pyretic agent at a dose of $20 \mathrm{mg} / \mathrm{kg}$ [16]. Thirty minutes after administration of 2,4-DNP, pyrexia was confirmed in the rats. The animals were divided into 5 groups of 4 animals each and the different treatments were administered as follows:

Group 1- Distilled Water $(10 \mathrm{ml} / \mathrm{kg})$

Group 2- SPM $(50 \mathrm{mg} / \mathrm{kg})$

Group 3- SPM (100 mg/kg)

Group 4- SPM (200 mg/kg)

Group 5- Paracetamol (100 mg/kg)

The rectal temperature was then recorded at $1,2,3$ and 4 h posttreatment $\left(\mathrm{T}_{\mathrm{x}}{ }^{\circ} \mathrm{C}\right)$.

$$
\% \text { reduction in temperature }=\frac{T_{0}-T_{x}}{T_{0}-\text { Basal Temp }} \times 100
$$

Brewer's yeast-induced pyrexia

The method described by Sengar et al., (2015) [17] was used. The basal rectal temperature of the rats were measured by inserting a clinical thermometer, $3-4 \mathrm{~cm}$ into the rectum. Pyrexia was induced in the animals which have been fasted for $18 \mathrm{~h}$, by subcutaneous administration of $15 \%$ (w/v) of the Brewer's yeast diluted in $0.95 \%$ saline solution at a dose of $10 \mathrm{mg} / \mathrm{kg}$. Following the injection, the rectal temperature of the rats was measured $18 \mathrm{~h}$ after the brewer's yeast injection to confirm pyrexia. The animals were grouped into 5 groups $(n=4)$ and passed through the same treatment schedule.

The rectal temperature was then recorded at 1, 2, 3 and 4 h post-treatment $\left(\mathrm{T}_{\mathrm{x}}^{\circ} \mathrm{C}\right)$.

$$
\% \text { reduction }=\frac{\mathrm{T}_{0}-\mathrm{T}_{\mathrm{x}}}{\mathrm{T}_{0}-\mathrm{Basal} \mathrm{Temp}} \times 100
$$


Agbaje, et al.

\section{Antimicrobial test}

In vitro demonstration of antimicrobial activity (sensitivity test)

Hugo and Rusell, (1998) method [18] was emplyed.

\section{Micro-organisms used}

Escherichia coli ATCC 25922

Bacillus subtilis ATCC 6633

Staphylococcus aureus (clinical strain)

Pseudomonas aeruginosa ATCC 10145

Bacillus subtilisi (clinical strain)

Candida albicans (clinical strain)

Aspergillus fumigatus (clinical strain)

Candida pseudotropicalis (clinical strain)

Aspergillus niger(clinical strain)

\section{Sample preparation}

Three working samples were prepared - $200 \mathrm{mg} / \mathrm{ml}$, $100 \mathrm{mg} / \mathrm{ml}, 50 \mathrm{mg} / \mathrm{ml}$

\section{Standard preparation}

Four working samples of each standard was prepared for each standard

Ciprofloxacin - 20, 10, 5, 2.5 $\mu \mathrm{g} / \mathrm{ml}$

Clotrimazole $-40,20,10,5 \mu \mathrm{g} / \mathrm{ml}$.

\section{Media Preparation}

Media was prepared according to manufacturer's instructions. Mueller Hinton agar (3.8 g per litre) was used for the antibacterial assay while Saboraud Dextrose Agar was used for the antifungal assay.

Twenty-five millilitres of the different agar type was dispensed in sample bottles in molten form and autoclaved at $121^{\circ} \mathrm{C}$ for 15 minutes. After autoclaving they were kept in the water bath at $50^{\circ} \mathrm{C}$ until ready for use.

Petri dishes were pre-labeled for use according to the organisms and media as well as the samples and standard concentrations.

\section{Assay Organisms}

All the assay organisms were sub-cultured from their various stocks onto their respective indicator media (diagnostic media). The bacteria were incubated at $37^{\circ} \mathrm{C}$ for $24 \mathrm{~h}$, while the fungi were left at room temperature and observed for 5-7 days until sporulation. The organisms were observed on the various media, after which the bacteria were subcultured on the Mueller Hinton Agar and the fungi were subcultured on the Saboraud Dextrose Agar after the identities have been confirmed. The Mueller Hinton plates were incubated for another $24 \mathrm{~h}$ and the fungi too were left for about 5 days to grow. Growths on the agar plates were further subcultured into sterile nutrient broth and incubated. The broth culture prepared was used for optical density adjustment for the assay.

\section{Calibration of Assay Organisms}

The liquid culture of the bacteria was dropped in sterile normal saline and fungi in Tween saline until the turbidity matched with 0.5 MacFarland turbidity standard.

\section{Seeding}

One millilitre of standardized organism suspension was mixed with $25 \mathrm{ml}$ warm sterile molten agar and pulpated and allowed to solidify.

\section{Cork Boring}

A cork borer of diameter $12 \mathrm{~mm}$ was flamed and allowed to cool to make it sterile. The sterile cork borer was used to cut portions of the solidified seeded agar and the cut portions were discarded in disinfectant jar. The cork borer was flamed and cooled again before using for the next organism to avoid cross contamination.

\section{Dispensing of Standards and Samples}

Different concentrations of standards and samples were dispensed in the appropriately labeled cut out portions. The plates were allowed to rest for $4 \mathrm{~h}$ and incubated at $37^{\circ} \mathrm{C}$ for $24 \mathrm{~h}$ for bacteria and the fungal plates observed daily for 7 days.

The zones of inhibition around the bored hole for each organisms at different concentrations of the extract and sample were measured afterwards.

\section{Minimum Inhibitory Concentration}

Different concentrations of the extract were prepared by diluting the stock with different strength of agar to make up to $20 \mathrm{ml}$, which was poured in the petri dishes. The working concentrations were $0.1,0.2,0.4,0.8,1.6,3.2,6.4,12.8,25.6$, $51.2,60,70,80,90$ and $100 \mathrm{mg} / \mathrm{ml}$. The petri dishes were prelabelled before pouring the already prepared agar and extract mixture. The agar was left to solidify after which drops of the different calibrated agar was put on the solidified agar [18]. Plates were observed for $72 \mathrm{~h}$ for any bacterial growth and the concentrations at which there was no visible bacteria growth was recorded.

\section{Minimum Bactericidal Concentration}

Agar was prepared and poured into pre-labelled petri dishes. The agar was left to solidify after which the bacteria with invisible growth on the plates of the minimum inhibitory concentrations was transferred to the surface of the agar to confirm if its total death or it was just in an inactive state [18]. The concentration at which the bacteria were completely dead and not just inactive were recorded as the minimum bactericidal concentration.

\section{Statistical Analysis}

Results expressed as mean \pm SEM. Two- way ANOVA was used to analyse the significance of the results. 


\section{RESULTS}

\section{Physicochemical Properties of the Extract}

Colour of extract - Dark brown

Taste of extract - Sour

Smell of extract - Medicinal

Texture of extract - Sticky

Nature of extract - Deliquescent

Solubility in water - Soluble

pH - 4.9

Percentage yield - 14.68

\section{Phytochemical Screening}

The phytochemical screening of SPM showed the presence of tannins, cardiac glycosides, flavonoid, reducing sugar, steroids, terpenes and absence of alkaloids, anthraquinones, and saponins (Table 1).

\section{Acute Toxicity}

In the oral acute toxicity test carried out in mice, the extract did not produce any toxic symptoms or mortality up to dose level of $4000 \mathrm{mg} / \mathrm{kg}$, hence, the extract was considered safe.

For the intraperitoneal route, doses below $1000 \mathrm{mg} / \mathrm{kg}$, in the mice showed abdominal contraction and frequent bowel movements at a mean onset of action of fifteen minutes and sedation at a mean onset of action of 45 minutes. At $1000 \mathrm{mg} / \mathrm{kg}$, behavioural patterns included abdominal contraction at mean onset of action of 12 minutes with duration of action of 30 minutes, frequent bowel movements, sedation at a mean onset of action of 45 minutes and mean duration of action of 2 hours 31 minutes and an actual time of death above 3 hours onset of action.

The median lethal dose $\left(\mathrm{LD}_{50}\right)$ via intraperitoneal route was calculated as $707 \mathrm{mg} / \mathrm{kg}$.

\section{Antioxidant Capacity}

The DPPH radical quenching of the extract indicated potent radical scavenging activities, but weaker than the standard ascorbic acid used (Figure 1).

Table 1: Qualitative and quantitative analyses

\begin{tabular}{lcc}
\hline Phytoconstituents & Qualitative & Quantitative $\mathrm{mg} / 100 \mathrm{~g}$ \\
\hline Alkoloids & + & $12.00 \pm 0.26$ \\
Flavonoids & + & $37.00 \pm 0.36$ \\
Phlobatanins & + & \\
Tannins & + & $24.00 \pm 0.17$ \\
Anthraquinones & + & \\
Reducing sugar & + & $33.00 \pm 0.60$ \\
Cardiac glycosides & + & $19.00 \pm 0.40$ \\
Steroids & + & $22.00 \pm 0.11$ \\
Saponins & + & \\
Phenols & + & \\
Terpenoids & + & \\
\hline Present & &
\end{tabular}

In the reducing power assay, the extract possesses a potent reducing power activity, which at low doses, was higher than ascorbic acid (Figure 2).

In this assay, the extract possesses a potent NO-scavenging activity as an antioxidant property, but not as high as the values recorded for ascorbic acid (Figure 3).

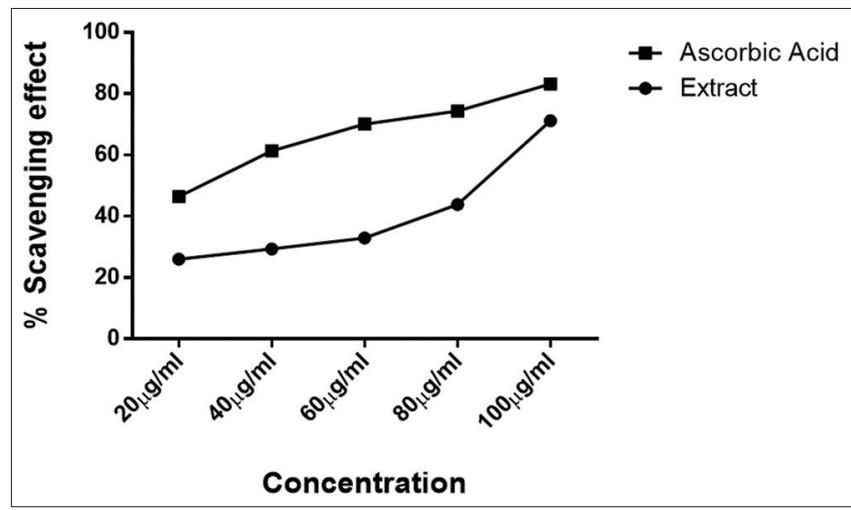

Figure 1: 1,1-diphenyl-2-picrylhydrazyl (DPPH) Radical Scavenging Activity. Values are mean \pm S.E.M. Extract $20 \mu \mathrm{g} / \mathrm{ml}: 26.04 \pm 1.11$, $40 \mu \mathrm{g} / \mathrm{ml}: 29.37 \pm 0.28,60 \mu \mathrm{g} / \mathrm{ml}: 32.96 \pm 0.28,80 \mu \mathrm{g} / \mathrm{ml}: 43.90 \pm 0.42$, $100 \mu \mathrm{g} / \mathrm{ml}: 71.90 \pm 0.83$

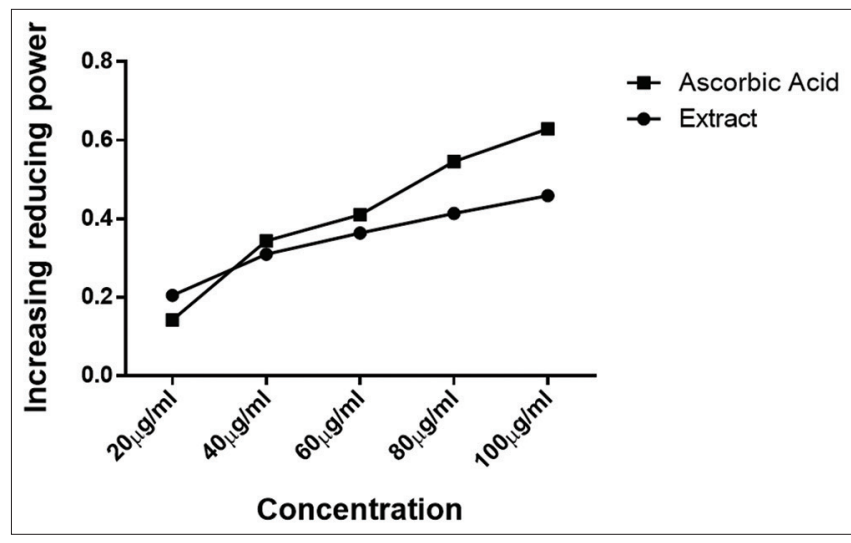

Figure 2: Reducing Power Assay. Ascorbic acid $20 \mu \mathrm{g} / \mathrm{ml}: 46.46 \pm 0.25$, $40 \mu \mathrm{g} / \mathrm{ml}: 61.38 \pm 0.09,60 \mu \mathrm{g} / \mathrm{ml}: 70.17 \pm 1.30,80 \mu \mathrm{g} / \mathrm{ml}: 74.40 \pm 0.12$, $100 \mu \mathrm{g} / \mathrm{ml}: 83.25 \pm 0.52$

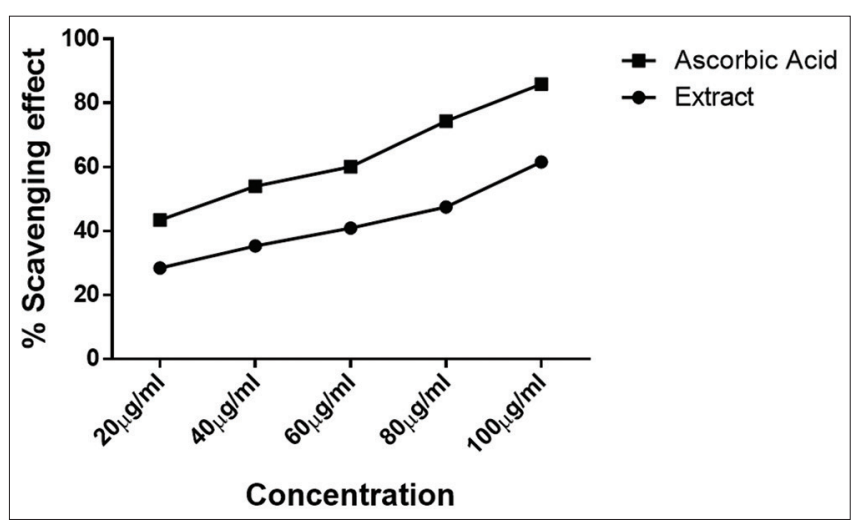

Figure 3: Nitric Oxide Scavenging Activity Assay. Values are mean \pm S.E.M. Extract $20 \mu \mathrm{g} / \mathrm{ml}: 0.205 \pm 0.001,40 \mu \mathrm{g} / \mathrm{ml}: 0.310 \pm 0.001$, $60 \mu \mathrm{g} / \mathrm{ml}: 0.363 \pm 0.002,80 \mu \mathrm{g} / \mathrm{ml}: 0.414 \pm 0.001,100 \mu \mathrm{g} / \mathrm{ml}: 0.459 \pm 0.003$ 


\section{Antimicrobial Result}

Sensitivity Test

The aqueous extract of SPM showed significant $(\mathrm{p}<0.05$, $\mathrm{p}<0.01, \mathrm{p}<0.001, \mathrm{p}<0.0001)$ antimicrobial activity when compared to the standard ciprofloxacin. The decoction at $50 \mathrm{mg} / \mathrm{ml}$ showed zones of inhibition but not in all bacteria, unlike with the higher concentrations of 100 and $200 \mathrm{mg} / \mathrm{ml}$, which recorded zones of inhibition in all the bacteria. A dosedependent effect was scored for all the organisms, with Staphylococcus aureus and Bacillus subtilis ATCC 6633 being the most susceptible to the herbal drug at $200 \mathrm{mg} / \mathrm{ml}$, recording the highest zone of inhibition of $38.2 \pm 0.3 \mathrm{~mm}$ (Figures 4 and 5).

Bacillus subtilis (clinical) with Bacillus subtilis(clinical)

different concentrations with different concentrations of of extract and solvent ciprofloxacin.

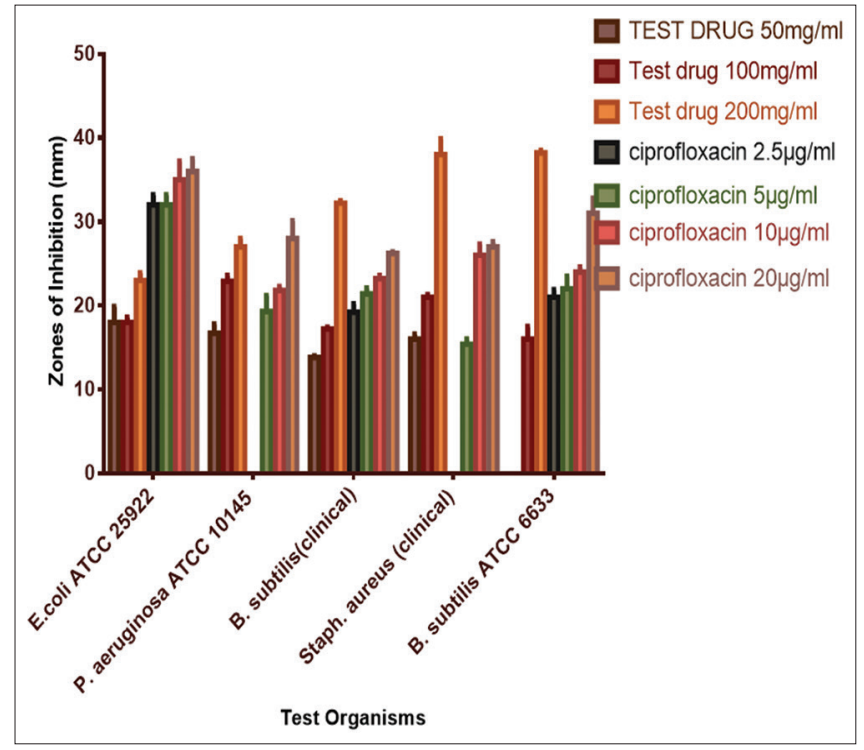

Figure 4: Bar chart showing Zones of InhibitionAgainst the different Test Organisms at Different Concentrations of the extract (Spondias mombin) and the Standard (Ciprofloxacin). Ascorbic acid $20 \mu \mathrm{g} / \mathrm{ml}$ : $0.142 \pm 0.003,40 \mu \mathrm{g} / \mathrm{ml}: 0.344 \pm 0.003,60 \mu \mathrm{g} / \mathrm{ml}: 0.410 \pm 0.001,80 \mu \mathrm{g} / \mathrm{ml}$ : $0.545 \pm 0.002,100 \mu \mathrm{g} / \mathrm{ml}: 0.629 \pm 0.003$
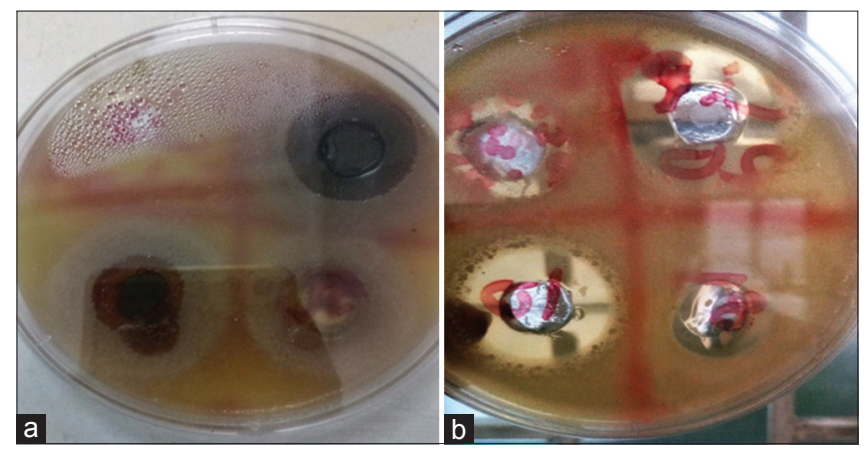

Bacillus subtilis (clinical) with Bacillus subtilis(clinical) different concentrations with different concentrations of of extract and solvent ciprofloxacin.

Figure 5: Pictures of the agar plates showing the zones of inhibition

\section{Minimum Inhibitory Concentration}

Staphylococcus aureus (clinical) and Pseudomonas aeruginosa ATCC 10145 had the lowest inhibitory concentration of $25.6 \mathrm{mg} / \mathrm{ml}$, while others had $60 \mathrm{mg} / \mathrm{ml}$ as their minimum inhibitory concentrations as shown in Figure 6.

\section{Minimum Bactericidal Concentration}

The minimum bactericidal concentration for each organism was also evaluated (Table 2).

\section{Antipyretic Activity of Spondias Mombin Extract}

Aqueous extract of SPM showed significant $(\mathrm{p}<0.05)$ antipyretic activity in the brewer's yeast and 2,4-DNP-induced pyrexia model as shown in Figures 7-10.

\section{Brewer's Yeast Induced Pyrexia}

Aqueous extract of SPM showed significant $(p<0.05)$ antipyretic activity in the brewer's yeast-induced pyrexia model as shown in Figures 7 and 8, howbeit, the highest dose of $200 \mathrm{mg} / \mathrm{kg}$

Table 2: Minimum bactericidal concentration

\begin{tabular}{lc}
\hline Organisms & MBC \\
\hline Escherichia coli ATCC 25922 & $70.0 \mathrm{mg} / \mathrm{ml}$ \\
Staphylococcus aureus (clinical) & $51.2 \mathrm{mg} / \mathrm{ml}$ \\
B. subtilis ATCC6633 & $60.0 \mathrm{mg} / \mathrm{ml}$ \\
P. aeruginosa ATCC10145 & $51.2 \mathrm{mg} / \mathrm{ml}$ \\
Bacillus subtilis (clinical) & $70.0 \mathrm{mg} / \mathrm{ml}$ \\
\hline
\end{tabular}

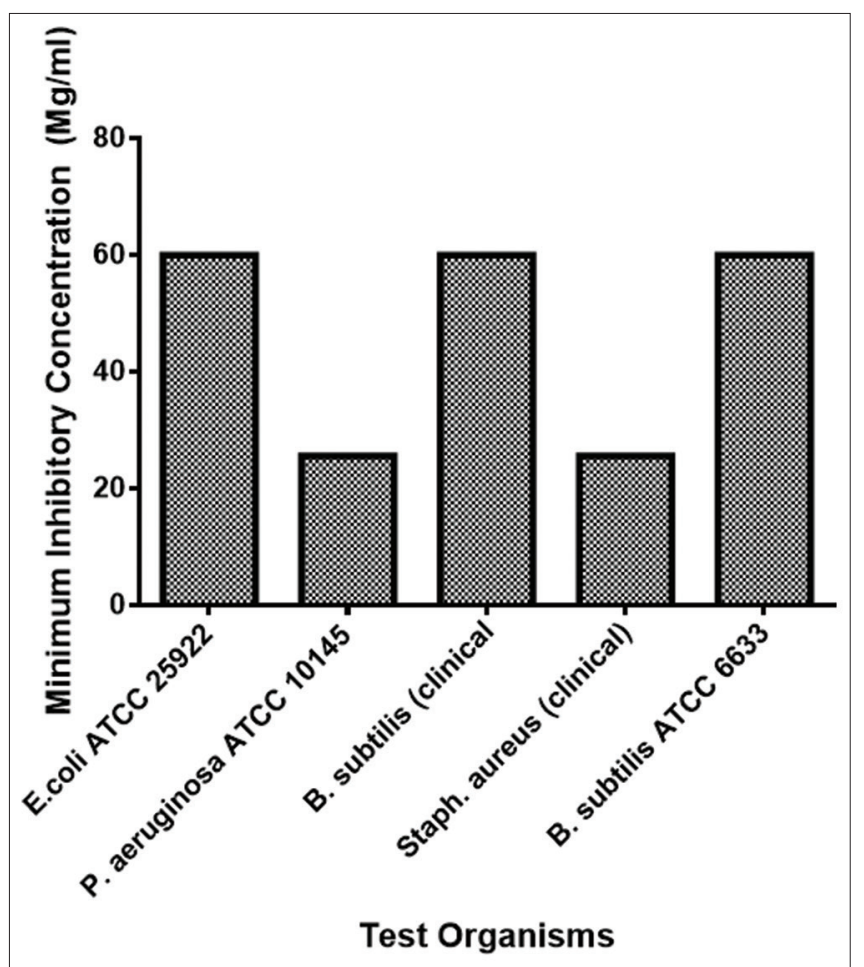

Figure 6: Bar chart comparing the Minimum Inhibitory Concentration of each organism 
produced the greatest efficacy, which was also superior to the standard drug paracetamol at the dose level employed.

\section{2,4-DNP Induced Pyrexia}

Similar to the other model, the aqueous extract of SPM showed significant $(\mathrm{p}<0.05)$ antipyretic activity, however, the efficacy of paracetamol was greater than the extract at all doses employed (Figures 9 and 10).

\section{DISCUSSION}

The study was designed to explore the antimicrobial and antipyretic activities of SBM as claimed by herbal users and traditional medicine practitioners, and to compare its possible efficacy with standard drugs.

Despite the wide range of available conventional antimicrobials, the microbes render them ineffective through resistance development. An important potential strategy to help combat the resistance problem involves the discovery and development of new active agents capable of partly or completely suppressing bacterial resistance mechanisms [19].

Investigating the antimicrobial potential of SPM using the sensitivity test with Escherichia coli ATCC 25922, Pseudomonas

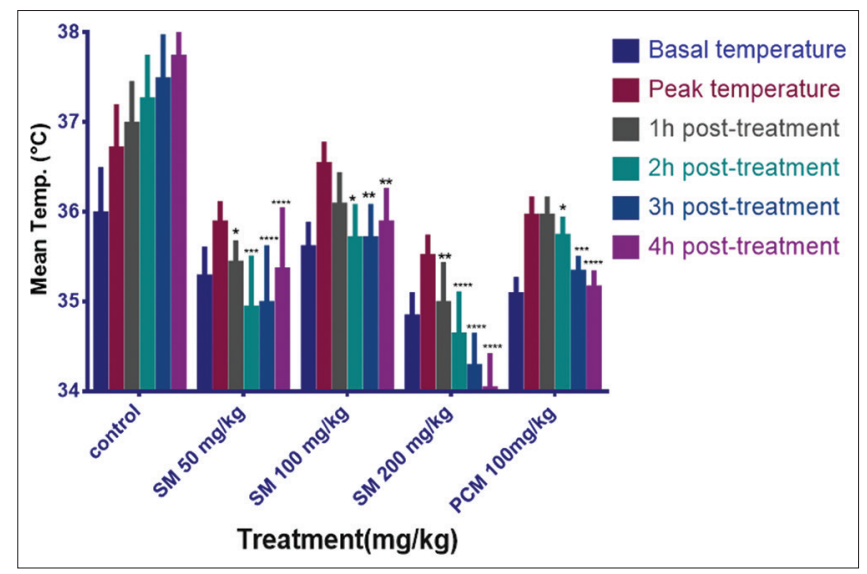

Figure 7: Bar chart showing reduction in Temperature $\left({ }^{\circ} \mathrm{C}\right)$ after treatment. Values are mean \pm SEM $(n=4){ }^{*} p<0.05,{ }^{* *} p<0.01$, ${ }^{* * *} \mathrm{p}<0.001,{ }^{* * * *} \mathrm{p}<0.0001$ when compared to control. (Two-way ANOVA followed by Dunnett's multiple comparison test

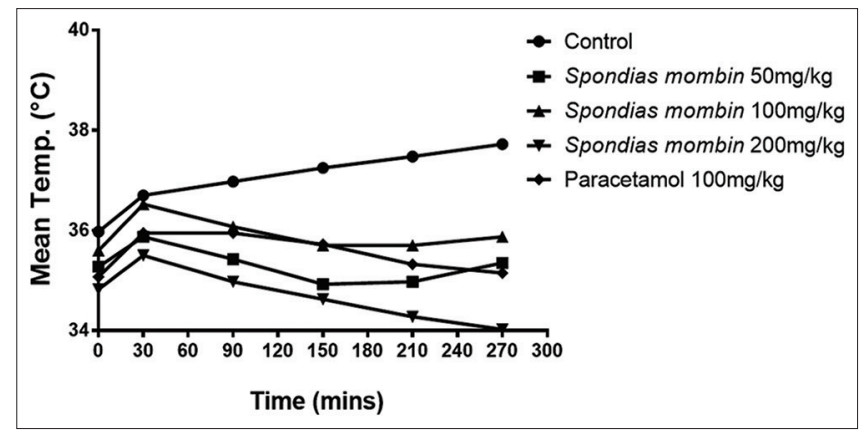

Figure 8: Linear curve showing Mean Temperature $\left({ }^{\circ} \mathrm{C}\right)$ against Time (min) aeruginosa ATCC 10145, Bacillus subtilis (clinical), Staphyloccoccus aureus (clinical), Bacillus subtilis ATCC 6633, Aspergillus fumigatus, Aspergillus niger, Candida albicans, Candida pseudotropicalis showed antibacterial effect in all the bacteria specimens used. The highest zone of inhibition was $38.2 \pm 0.3$ at the concentration $200 \mathrm{mg} / \mathrm{ml}$ against Bacillus subtilis ATCC 6633 and Staphylococcus aureus. The extract of SPM produced a significant $(\mathrm{p}<0.05)$ and a dose dependent antibacterial activity; the finding which is in congruence with the report of Okwulehie and Akanwa, (2013) [20], who reported on the leaf ethanolic extract. It is however noteworthy that SPM compared well with the standard drug at every concentration tested.

The extract did not show any zone of inhibition against the fungi used; rather it supported the growth of the fungi by reducing the time required for sporulation, thereby hastening sporulation for the spore forming fungi such as Aspergillus sp.

The present study revealed that the aqueous extract of SPM possesses antibacterial, but not antifungal activity among the microorganisms assessed.

The Minimum inhibitory concentration, from which the potency of the extract for each organism could be compared was further evaluated. SPM extract recorded the highest potency against Staph. aureus and P. aeruginosa with MIC of $25.6 \mathrm{mg} / \mathrm{ml}$.

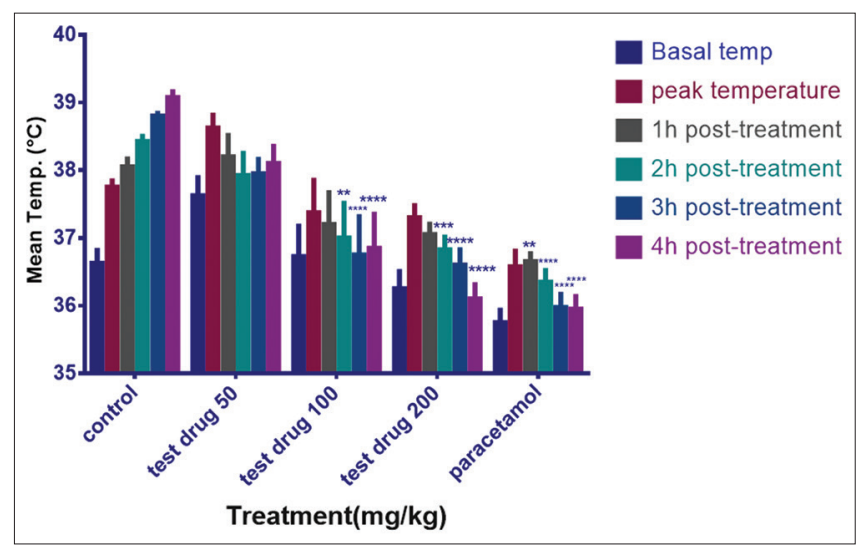

Figure 9: Bar chart showing reduction in Temperature $\left({ }^{\circ} \mathrm{C}\right)$ after treatment. Values are mean \pm SEM $(n=4){ }^{*} p<0.05,{ }^{* *} p<0.01$, ${ }^{* * *} p<0.001,{ }^{* * * *} p<0.0001$ when compared to control. (Two-way ANOVA followed by Dunnett's multiple comparison test

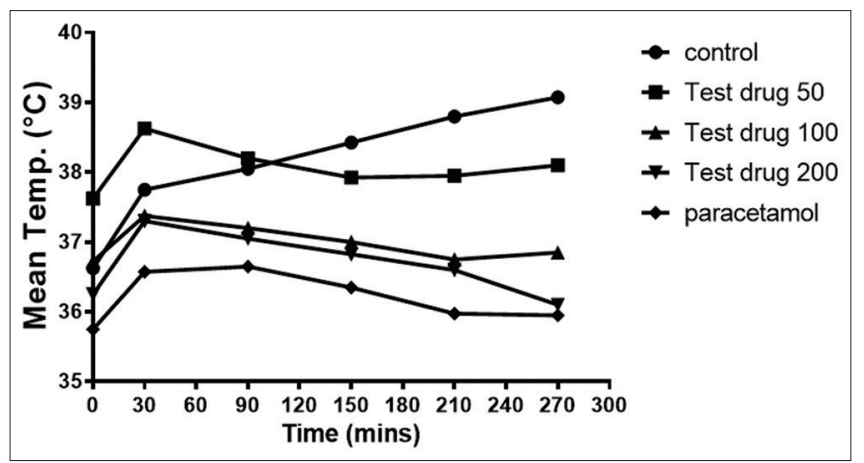

Figure 10: Linear curve showing the Mean Temperature $\left({ }^{\circ} \mathrm{C}\right)$ against Time (min) 
The Minimum Bactericidal Concentration was also determined for each organism to check the bactericidal activity of the extract. This tells whether the extract kills the bacteria and the lowest concentration at which the extract completely kills it. The minimum bactericidal concentration for each bacterium was determined to be: E. coli- $70 \mathrm{mg} / \mathrm{ml}$, Staph. aureus $-51.2 \mathrm{mg} / \mathrm{ml}$, B. subtilis ATCC $6633-60 \mathrm{mg} / \mathrm{ml}$, P. aeruginosa- $51.2 \mathrm{mg} / \mathrm{ml}$ and B. subtilis (clinical) $-70 \mathrm{mg} / \mathrm{ml}$.

On the antipyretic study, pyrexia is one of the most common signs of illness and it is best defined as an increase in temperature over what is normal for a given individual at that particular time of the day. It is a natural defense mechanism or response to tissue damage, inflammation, malignancy or graft rejection [21].

Normally, damaged or infected tissues initiate enhanced formation of pro-inflammatory mediators (cytokines such as interleukin $\alpha$ and $\beta$, Tumour Necrosis Factor- $\alpha$ ), which increases synthesis of prostaglandin (PG) $E_{2}$ near the hypothalamic area and thereby triggers the hypothalamus to elevate the body temperature [22]. Most of the antipyretics inhibit cyclooxygenase-2 expression, thus inhibiting $\mathrm{PGE}_{2}$ biosynthesis and consequently reduce the elevated body temperature $[21,23]$.

Both the Brewer's Yeast and the 2,4-Dinitrophenol-induced models demonstrated antipyretic property of SPM, which compared effectively with paracetamol.

Brewer's yeast induces both TNF- $\alpha$ and prostaglandin synthesis. Hence, inhibition of the higher level of prostaglandin $\mathrm{E}_{2}$ synthesis by SPM reduces elevated temperature and maintains it as normal body temperature. Trend of activity was both dose and time dependent, and the extract was observed to reduce the temperature below the basal level at the highest dose given, unlike the standard drug. Furthermore, at $200 \mathrm{mg} / \mathrm{kg}$ dose, the extract activity was found to be superior to the standard drug.

2,4- Dinitrophenol is considered to be a classic uncoupler of oxidative phosphorylation. It is a synthetic proton ionophore that dissipates proton gradient across bioenergetic membranes (mitochondrial inner, thylakoids, and bacterial plasma). In the presence of 2,4-DNP, electron transport continues even at an accelerated rate, but ATP production is diminished. The energy that should have been converted to chemical energy in form of ATP is then converted to excess heat causing pyrexia [24]. In this study 2,4-DNP was able to induce pyrexia in the rats after 30 minutes of administration; extract effect was significant $(\mathrm{p}<0.0001)$ only at 100 and $200 \mathrm{mg} / \mathrm{kg}$ doses, as well as with paracetamol.

The phytochemical test carried out on the extract showed the presence of flavonoids tannins, reducing sugar, cardiac glycosides, steroids and terpenes, alkaloids, anthraquinones and saponins. One or a combination of this phytoconstituents may be responsible for the antimicrobial and antipyretic activities of SPM as observed in this study, especially as synergy is an important concept in the pharmacology of phytochemicals of botanical medicines [25]. Phenols including flavonoids have been shown to possess various pharmacological and biochemical actions including antipyretic and anti-inflammatory properties [25]. Terpenes also play a role in traditional herbal remedies and are under investigation for antibacterial and antineoplastic properties [26]. Tannins on the other hand have been identified with bactericidal property [27].

The antioxidant capacity of SPM evaluated was less than ascorbic acid in assessing 1,1-diphenyl-2-picrylhydrazyl (DPPH) radical scavenging activity, and nitric oxide scavenging activity, while its reducing power compared well with the standard.

The acute toxicity test of the plant decoction showed that the extract is safe for oral use, as there was no mortality recorded with oral administration up to a dose of $4000 \mathrm{mg} / \mathrm{kg}$ in mice. The $\mathrm{LD}_{50}$ of $707 \mathrm{mg} / \mathrm{kg}$ was recorded for the intraperitoneal route.

\section{CONCLUSION}

The present study demonstrates that the aqueous leaf extract of SPM possesses antibacterial and antipyretic properties, which justifies the use of the extract in traditional medicine for the treatment of infections and febrile conditions. SMB aqueous extract compared well with the standard drugs employed in the study. A bioactivity guided fractionation of the extract will reveal the specific chemical agent(s) responsible for the observed effects of SPM and the exercise could also possibly throw up lead compound(s) for the development of newer, more efficacious and better tolerated drugs for the treatment of infections and pyrexia.

\section{REFERENCES}

1. Anochie I. Mechanisms of fever in man. International Journal of Microbiology and Immunology. 2013; 2(5):37-43.

2. Institute of Health Metrics and Evaluation (IHME). Global Burden of Disease Study. Lancet. 2014; 385 (9963): 117-71.

3. Oguntokun O, Emmanuel I, Soyinka J, Onocha PA and Oloyede GK Phytochemical Screening, antimicrobial and antioxidant activities of Four Nigerian Medicinal plants. Annals of Biological Research. 2010; 1(2):11-120.

4. World Health Organization (WHO) 2008. The World Health Report 2008: Primary Healthcare - Now More Than Ever.

5. Aliyu MS, Hanwa UA, Tijani MB, Aliyu AB, Ya'u B. Phytochemical and Antibacterial Properties of Leaf Extract of Stereospermum kunthianum (Bignoniaceae). Nig. J. Basic Appl. Sci. 2009; 17(2):235-239.

6. Ayoka AO, Akomolafe RO, Akinsomisoye S and Ukponmwan OE. Medicinal and Economic value of Spondias mombin. African Journal of Biomedical Research. 2008; 11(2):129-136.

7. Trease G, EvansWC. Pharmacognosy, 2002; 15 th Edn. Saunders, pp. 214-393.

8. Harbones AJ. Phytochemical Methods: A Guide to modern techniques of plants analysis 1998. Chapman Hall Ltd, London.

9. Ejikeme CM, Ezeonu CS, Eboatu AN. Determination of physical and phytochemical constituents of some tropical timbers indigenous to Niger Delta area of Nigeria. Eur. Sci. J. 2014; 10(18): 247-270.

10. Obdoni BO, Ochuko PO. Phytochemical studies and comparative efficacy of the crude extract of some Homostatic Plants in Edo and Delta states of Nigeria. Glob. J. Pure and Appl. Sci. 2001. 7(3): 455-459.

11. Bohn BA, Kocipai AR. Flavonoid and condensed tannins from leaves of Hawaiian Vaccinium vaticulatum and V. calycinium, Pacific Science. 1994; 48: 458-463.

12. Cuendet M, Kurt H, Oliver P and Wahjo D. Indoid Glucosides with free radical scavenging properties from Fagraea blumei. Helvetica 
Chimica Acta 80(4):1144-1152

13. Solati Z, Baharin BS, Bagheri H. Antioxidant property, thymoquinone content and chemical characteristics of different extracts from Nigella sativa L. sseeds. J. Amer. Oil Chemists' Society. 2014; 91(2): 295-300.

14. Harinder PS, Siddhuraju MP, Becker K. Nitrate and Nitrite, Plant Secondary Metabolites, 10.1007/978-1-59745-425 7, (33-39), 2007.

15. Lorke D. A new approach to pratical acute toxicity testing. Arch Toxicol. 1983; 54: 275-87.

16. Liu S, Lu F, Wang X, Sun W, Chen P, Dong W. Metabolomic Study of a rat fever model induced with 2,4-dinitrophenol and the therapeutic effects of a crude drug derived from Coptis chinensis. The Amer. J. Chin. Med. 2011; 39(1): 95-109.

17. Sengar N, Joshi A, Prasad SK et al. Antiinflammatory, analgesic and antipyretic activities of standardized root extract of Jasminum sambac. J. Ethnopharmacol. 2015; 160: 140-8.

18. Hugo and Rusell. Pharmaceutical Microbiology, $8^{\text {th }}$ ed./Denyer, S, Hodges N, Gorman S, Gilmore B. Wiley-Blackwell, 2011. 524p.

19. Bakal SN, Bereswill S, Heimesaat MM. Finding novel antibiotic subsatnces from medicinal plants - Antimicrobial properties of Nigella sativa directed against multi-drug resistant bacteria. Eur. J. Immunol (Bp). 2017; 7(1): 92-98.

20. Okwulehie IC, Akanwa FE. Antimicrobial Activity of Ethanol Extract of four Indegenous Plants from South Eastern Nigeria. 2013. 3(4):
350-355.

21. Bhattacharya A, Behera R, Agrawal D, Sahu PK, Kumar S, Mishra SS. Antipyretic effect of ethanolic extract of Moringa oleifera leaves on albino rats. Tanta Med. J. 2014; 42(2): 74-78.

22. Esther O. Agbaje and Oluwole A. Ajidahun. Analgesic, antiinflammatory and antipyretic effects of dried root ethanolic extract of Strophanthus sarmentosus p. Dc (Apocynaceae). Int. Res. J. Pharm. Pharmacol. 2011; 1(4): 062-069.

23. Thangaraj AP, Moorthi M, and Senthilkumar A. A Study the effect of Biofertilizer Azotobacter Chroococcum on the Growth of Mulberry Cropmorus Indica L. and the Yield of Bombyx Mori L 2016. Int. J. Envir. Agric. Biotech. 1(4):853-856.

24. Ettebong EO, Nwafor PA. Antipyretic and Antioxidant activities of Eleucine indica. The J. Phytopharmacology 2015; 4(4): 235-242.

25. Larkins, N., Wynn, S. (2004). Pharmacognosy: Phytomedicines and their mechanisms. Vet. Clin. N. Amer. Small Anim. 34: 291-327.

26. Sieniawska E, Swartko-Ossor M, Sawicki R, Skalicka-Wozniak K, Ginalska G. Natural Terpenes influence the Activity of Antibiotics against isolated Mycobacterium tuberculosis. Med. Princ. Pract. 2017; 26: 108-112.

27. Adnan SN, Ibrahim N, Yaacob WA. Distruption of methicillin-resistant Staphylococcus aureus protein synthesis by tannins. Germs. 2017; 186-92. 